\title{
Current and Future Prospects for the Bologna Process in the Turkish Higher Education System
}

\author{
Armağan Erdoğan
}

\section{Introduction}

The fundamental questions of "what a university is" and "what kind of graduate it will produce" have persisted since the birth of universities. In the 21 st century, these questions have become more significant for different reasons and under different conditions (Scott 2006). The interaction between trends in globalization and higher education have brought new conditions, opportunities and challenges to higher education systems, which then needed new policies and structures (Altbach and Peterson 1999; Cortese 2003; Enders 2004; Scott 2005; Altbach et al. 2009; OECD 2009). This change has influenced national approaches of the countries and has also been the outcome of global trends in social, cultural, political, economic, and technological developments (Bloom 2005; Altbach et al. 2011; Stromquist and Monkman 2014). More specifically, global economic competition required human resources qualified for the requirements of the age, and higher education systems faced the need for both structural and content reforms (Gibbons 1998). In other words, the realities and requirements of our age directed higher education systems to pursue reforms in teaching, research, and public responsibility functions (Arnove et al. 2012). Common experiences, common challenges and common targets created regional partnerships in order to form new policies, mechanisms, and tools (Sursock and Smidt 2010). In this sense, the Bologna Process (BP) arises as a unique international and regional cooperation to respond to the needs of transparency, comparability and recognition in European higher education (Eurydice 2009).

The Bologna Process has reached a critical threshold in its 15 th year. Its geographical scope has been enlarged and its substance diversified since its beginning in 1999. The national, international and institutional experiences within this period

\footnotetext{
A. Erdoğan $(\bowtie)$

Social Sciences University of Ankara, Ankara, Turkey

e-mail: armagan.erdogan@asbu.edu.tr

(C) The Author(s) 2015

A. Curaj et al. (eds.), The European Higher Education Area,

DOI 10.1007/978-3-319-20877-0_46
} 
have created valuable common understanding and knowledge (EHEA 2012; Gaston 2010). The Bologna Process succeeded in establishing the European Higher Education Area (EHEA) with 47 countries, international organizations and stakeholders as consultative members, eight Ministerial Conferences, six Communiques, and two Declarations. The stocktaking reports, based on the self-evaluated national reports by each country, seem to be an innovative feature to follow up the implementation levels in each tool. Bologna Follow up Group (BFUG) meetings and a huge amount of work in different topics are other powerful aspects continued on a voluntary base. Moreover, the BP has attained a more global vision since (Bologna Process 2009), as the Bologna Policy Forum was established to extend regional cooperation to the rest of the world. Now, it is in the critical stage to evaluate the outcomes and challenges in order to suggest a roadmap for 2020 and beyond.

This article aims to contribute to the future prospects of the BP by examining Turkey's experiences. It is significant because Turkey's experience of the BP is not discussed very often in either its national or international dimension (Erdoğan 2013). Therefore, in the first section of the article, the experiences of Turkey will be examined through its commitments, regulations, and implementations so far. Another reason for which Turkey's experience might be significant, both for the other countries and for the future of the EHEA as a whole, is that it is a dynamic system which has been enlarged dramatically in the past decade. Challenges and policies to overcome the challenges might inspire other countries. For this reason, in the second section, in-depth interviews with semi-structured questions, conducted with 20 key actors, including policy makers, rectors, ex-rectors, vice rectors, Bologna experts, academic staff, and student representatives, will be analyzed in order to examine the reflections of the implementations on national and institutional basis. The participants were chosen for their knowledge and experience during the implementation of Bologna tools, from various higher education institutions, namely public and foundation, old and new, big and small ones from different parts of the country. Their answers, therefore, will represent an overall approach to the implementation experience. The participants' names and their institutions were kept confidential, their answers were categorized according to salience, and important points were stated in the text. Based on the experiences of Turkey in the BP, the article will offer some recommendations for the future of the EHEA.

\section{The Bologna Process in Turkey: Implementation, Challenges and Lessons Learned}

Common trends in global higher education, such as internationalization, mobility, cooperation with the stakeholders etc., are reflected in the current developments in Turkish higher education. In the meantime, Turkey, as a country, and its higher education system have some peculiarities which may be of relevance to other countries. At the same time, it has significant unique experiences that are particular to Turkey. Therefore, the aim of this paper is twofold. The first one is that this paper 
believes that analysing the Turkish case may contribute to the new road map in the future of the EHEA. The second is that it calls for a more concrete contribution of the BP in reforming the Turkish higher education.

Perhaps the first distinctive peculiarity is the geopolitical uniqueness of Turkey. Its rich historical and cultural background places Turkey in a special position between Europe, the Middle East, Central Asia, and the Mediterranean. Moreover, politically, because of its longstanding candidacy for EU membership, Turkey has a unique position. It benefits from some of the European Commission's education and research programs, but remains outside of the EU decision making processes.

The second significance of the Turkish higher education is that, following the demographic needs, Turkey has been, perhaps, the most rapidly growing higher education system in the EHEA. Access to higher education has been one of the crucial challenges that Turkey has faced over the decades. In order to decrease the gap between supply and demand, new universities have been established and extended enrolment capacity for programs has been applied (Erdoğan and Toprak 2012). These increased the enrolment rate, equal opportunity in access to some extent, enlargement and diversity of higher education institutions. With these developments, higher education has been massified in Turkey from 2000 onwards.

The current higher education system was created in 1981 and mentioned in the Constitution. The Council of Higher Education (YÖK 2007) was established as a corporate body responsible for planning, organizing, and supervising the teaching activities of higher education institutions. However, this structure, planned to coordinate around 27 universities in 1981, is not able to keep up with the numbers of higher education institutions in 2014 and the speed with which new institutions have been established. Economic and political developments in the last decade as well as the country's demographic trends have led to quantitative changes in higher education (Tuzcu 2006). Turkey became a member of the BP in 2001, and since then the number of higher education institutions has increased from 76 to 184 , students from 1.6 to 5.5 million (including distance education), and academic staff from 68 thousand to 140 thousand in 2014. Moreover, population projections show that the demand for higher education will continue to increase for decades in Turkey, therefore an important and challenging topic of the current agenda is the need for some structural reforms (Tenth Development Plan 2014-2018 2013). Out of this need evolved different drafts for a new higher education act; nevertheless, no result has been achieved thus far. Increasing the number of universities and enrolment rates is very positive in terms of equal opportunities for socio-economic reasons, but the quality, particularly in newly established universities, remains a big challenge (Erdoğan 2014).

Examining the recent developments of the system, they have been done not to systematically revolutionize the system, but have rather been needs-based revisions. Quantitative developments require further structural and contextual reforms on national and institutional levels. On one hand, the rapid growth Turkey experienced in the last decade highlights the dynamism of the system, which, on the other hand, brings its own challenges. Following the recent developments, the key priority of the system lies on quality. In a report by the former president of YÖK, three 
strategic priorities for Turkish higher education were defined as transition from quantity to quality development; developing human resources in academia; and internationalization of higher education (Çetinsaya 2014: 174). Similar objectives were noted and announced by a decision of the General Board of YÖK in 2011. They are in line with the priorities for the coming decades stated in the Bucharest Communique in 2012 (Bologna Process 2012) as investing in higher education for the future; providing quality education for all; enhancing employability to serve Europe's needs; strengthening mobility for better learning; and improvement of data collection. Although the priorities for the coming decades are in common, the BP has not been adopted in the new policy developments in Turkey. The BP was regarded as a mechanism to increase quality and to help internationalization of higher education, but it is not easy to say that the targets or the tools have been fully internalized. It is not always involved systematically with the new reforms in the system, and not related with the core functions of the higher education. Here comes the second aim of this article that is to underline that for the systematical restructuring of the higher education, the Bologna Process provides useful mechanisms for Turkey. Therefore, policy makers need to be aware of the common targets with the Bologna Process.

\subsection{What Has Been Achieved? What Are the Challenges Ahead?}

YÖK is the national authority in Turkey for coordinating the BP implementation; therefore, the implementation has been done in a more top-down process, depending on the requirements by YÖK nationally and the rectors institutionally (Elmas 2012). The top-down implementation process, which can be observed in some other countries as well, has both positive and negative effects. In the Turkish case, it is positive because, following the timetable and format of the commitments, it becomes possible; it is negative since some institutions resist the top-down approach, and implementation becomes artificial if the institutions and academic staff do not internalize them. As a positive example, in 2009 YÖK defined principles and guidelines and asked each higher education institution to set up a Bologna Coordination Committee (BEK) in order to coordinate, lead, and report on the implementation process. These Committees played an important role not only for institutional implementation and monitoring, but also for collecting reliable data nationwide. This positive national experience can be shared by other EHEA countries.

Examining the scorecard records, it is clear that of the three basic tools, the degree systems have been the most comfortable one for Turkey, as it had already been adopted in 1981. In this sense, Turkey has been in front of "the Humboldtian systems", as well as the post-communist systems, as they had to struggle with establishing the three cycle degree system. Work on preparing the national qualifications framework for higher education, however, was not focused until 2008. As stated in the 2012 national report, YÖK adopted the National Qualification Framework 
(NQF) for higher education in 2011. Pilot universities were chosen for implementation, and all institutions were asked to complete their implementation processes by 2012. In the meantime, the Professional Qualifications Authority (MYK) worked on the umbrella qualifications framework for all levels comparable with EQF, and this is about to be approved by the Cabinet. After the approval and the self-certification of the Turkish Qualifications Framework for Higher Education, it will be possible for higher education institutions to prepare more realistic program qualifications and curriculum design linked with learning outcomes and ECTS of the courses.

Perhaps the least developed tool of the Bologna Process in Turkey is a national Quality Assurance Agency, which has still not been established. According to the higher education law, faculties and universities are opened by Parliament upon the suggestion of YÖK and the Ministry of Education; and all higher education institutions and programs are opened and accredited by YÖK, which evaluated the initial quality assurance when universities applied for new programs. Nevertheless, for the outcomes of the higher education programs no systematic steps were taken for external quality assurance. After the Bergen Conference, a national Commission of Academic Evaluation and Quality Improvement in higher education institutions (YÖDEK) was established to coordinate quality assurance regulation compatible with the ESG. Academic Evaluation Committees (ADEK) were established in each higher education institution as an internal quality assurance mechanism. The secretary was provided by YÖK, however the Inter-University Board, where rectors from each university have the right to vote, chose the YÖDEK members. The capacity of YÖDEK was insufficient to function as a national body for a rapidly developing system. Some alternatives for a national quality assurance agency have been discussed, one of which is to convert YÖK into a national QA body. It becomes almost a deadlock. Without making a decision about the future role of YÖK, it is difficult to decide on any form of the QA agency. YÖK is a body established by the constitution and cannot be transformed only by law. As a result, in 2014 a new commission (YÖKAK) on quality assurance was formed to replace YÖDEK covering qualifications, as well as recognition issues nationwide. YÖKAK is now working on regulations for a quality assurance system in Turkey; after a consultation process, the regulation will come into force.

Mobility is the most visible effect of the globalization of higher education and many mechanisms have been created to address the need for mobility. EU Mobility programs not only contributed to the system's internationalization, but also inspired some new nationally provided exchange programs. In 2009 the Farabi mobility program was implemented in the system for student and staff exchange within the country and it helped many newly established universities experience mobility tools and culture. In 2012 the Mevlana exchange program - the international counterpart of Farabi-began for countries outside the Erasmus programs and totally provided for by national financial resources. In 2010, YÖK removed the central exam for foreign students to enter Turkish universities. Since then, foreign students started to be enrolled according to the criteria of each university. As another mechanism, a new institution called Turks Abroad and Related Communities (YTB) united the grants for international students who wished to study in Turkey under the name of 
“Turkey Scholarship". Nevertheless, there is no mobility and/or internationalization strategy on a national scale. Because of the high numbers of student population, although there is great effort, the mobility numbers are still low compared to the total student population.

The most outstanding development about the BP is the amendment of an article (44) in the Higher Education Act (HE Act 2011 No: 2547) in 2011. The article is a long paragraph about taking courses, evaluating the credits, student rights, and exams. It summarizes the basic tools of the BP and gives responsibility of running programs efficiently, calculating course credits in accordance with credits range and student work load, providing the minimum qualifications defined by the NQF in consultation with the stakeholders in order to increase the employability of graduates. In other words, this article embodies, for the first time, the key terms of the $\mathrm{BP}$ and conceptualizes learning outcomes, qualifications framework, credits based on student work load, internal and external quality assurance, recognition of prior learning, stakeholders, and employability in the law. It enforces credits based on student work load, without mentioning the ECTS.

Nevertheless, sustainability remains a critical issue since the agendas of the decision-makers, higher education institutions, academic staff, and students are not focused on the BP. The commitments or regulations have been done in a more top-down process, depending on the requirements by YÖK nationally and the rectors institutionally. Mainly because of the attractiveness of mobility, ECTS and DS are seen as key tools for Turkish higher education institutions in the short-term. In practice, the main challenge is that universities are still reluctant to make the shift from face-to-face credits, which is based on the total hours spent for the course in the classroom, to ECTS credits. In the cases where ECTS credits are implemented, credits are not necessarily defined and realized though student surveys. In reality, students, employers, and even university management do not regard them as beneficial for the quality of the degrees. There is either a lack of interest or criticism by certain groups, primarily based on political orientation to see the whole process as an imposition of the EU. Key actors and policymakers are not yet fully convinced of the necessity of the implementation, although quality assurance, mobility and internationalization have been popular terms in the higher education agenda in recent years. Internationalization is regarded as equal to mobility and particularly to attracting international students to the system. Therefore, implementation level differs according to institutions and is affected by the change of the top leaders.

\section{Perceptions of Key Actors Toward the Implementation of the Bologna Process}

In this section, the results of the focus group interviews, conducted with 20 different key actors - rectors, vice rectors, Bologna experts, academic staff, and studentswill be analyzed in relation to the national implementation level examined in the first section. In order to mirror the situation in Turkey, participants were chosen 
from different types of higher education institutions, such as public, foundation ${ }^{1}$; old, new; big, small; in big cities or in small cities. The interview list was composed of ten rectors, three vice-rectors who are leading Bologna Coordination Committees in their institutions, two Bologna experts, three student representatives, one representative from Ministry of National Education, and the President of YÖK. Their common ground is that they are or were actively involved in implementing the Bologna tools in Turkey. Their answers, therefore, will sum up the current issues and discussions of the Bologna Process in Turkey and will give insights and suggestions for the future of EHEA.

Each participant was asked five questions. The questions ranged from a general perception of the Bologna Process to more specific details on implementation experiences and recommendations for the future. The participants were asked open-ended questions, and further questions were included if needed to investigate their perceptions on the added value of the BP. The open-ended questions posed to the participants are as follows:

- What did the Bologna Process achieve in general?

- What kind of impact (positive/negative) has it had on Turkish higher education?

- What kind of experience did you have during implementation at your university?

- Based on your experiences, which priorities should EHEA have for the coming decade? Should structural reforms continue or should there be new priorities?

The first question, "What did the Bologna Process change in general?", attempted to understand the perceptions of the participants of the added value of Bologna Process in higher education systems (Table 1).

To list their comments on the added value of the BP, most of them, significantly, mentioned quality issues. The second most cited topic is that the BP brought comparability and transparency, because during the revision of the program outcomes the faculties and programs noticed some overlapping or unrealistic outcomes or courses in many of the big universities. Having seen similar learning outcomes in different courses in the same program, some courses were either combined or totally removed. Another significant comment is that it pushed higher education from a national to an international dimension. Turkish higher education became more self-confident about international partnerships after having been involved with the BP. The other most frequently mentioned change is that it brought new tools to the systems. Indeed in Turkey, the BP created a common vocabulary, such as qualifications framework, program/learning outcomes, student workload, social dimension, and lifelong learning in higher education. Mobility, employability, reform around common sense and discussion atmosphere are the other topics that participants mentioned. As a whole, the general perception of the added value of the BP is positive.

\footnotetext{
${ }^{1}$ According to the Turkish Higher Education Act 2547 foundations can establish non-profit higher education institutions. There are 74 foundation higher education institutions out of 184 total number that is $\% 40$.
} 
Table 1 What did Bologna process achieve in general?

\begin{tabular}{l|l}
\hline & $\begin{array}{l}\text { Frequency Out of } 20 \\
\text { participants }\end{array}$ \\
\hline It brought quality issues to the foreground & 16 \\
\hline It allowed comparability and transparency & 14 \\
\hline It transferred HE from a national to an international dimension & 12 \\
\hline It brought new instruments to HE systems & 12 \\
\hline It brought a discussion environment for HE needs & 10 \\
\hline It brought a chance for countries to revise their systems & 10 \\
\hline $\begin{array}{l}\text { It increased the mobility of not only young people, but also } \\
\text { academic staff }\end{array}$ & 7 \\
\hline It brought the idea of being united as in the USA & 6 \\
\hline It brought standards but also decreased diversity & 4 \\
\hline It is about the employability and profile of the graduates & 3 \\
\hline $\begin{array}{l}\text { It is an effort to create a regional vision and reform around } \\
\text { common sense }\end{array}$ & 3 \\
\hline
\end{tabular}

${ }^{a}$ Each participant may emphasize more than one proposition for each question; the table classifies their answers focusing on the same propositions. The same methodology has been followed for the subsequent tables

The second question was "what kind of impact (positive/negative) has it had on Turkish Higher Education?" The aim of this question was to see the comments of the participants, specifically the positive and negative impacts they have observed or perceived in Turkey (Table 2).

Of the positive effects, a majority of the participants agreed that it started a reform process in Turkish higher education, which highlights the positive impact of the BP on the system. Again, the majority thinks that it integrated Turkish higher education more with the international world. In the implementation process, the BP has been evaluated as a mechanism for internationalizing the system, and the answers of the participants support this approach. Similarly, it was commented that the BP also created a common ground for national discussions, and encouraged a common discourse on the shared challenges nationwide. One rector particularly stated that the idea of being a united Europe in higher education is an advantage, as in the case of the USA. With the BP, representations of the students at different decision making levels and in program developments, as well as relations with the employers and with the stakeholders are introduced to the system in a systematic and consistent way with the BP. These awareness raising topics and discourse of the $\mathrm{BP}$ also brought rationality to the programs and to the curricula; perhaps in the long term its utility will be visible.

On the other hand, the most cited negative impacts are the resistance of academic staff for different reasons and proforma implementation. Academic staff did not want to lose their "freedom" in defining (or not defining at all) the curriculum and the learning outcomes. Past habits of interpreting the role of the lecturer/professor as having a flexible curriculum troubled the more experienced staff members in 
Table 2 What kind of impacts has it had on Turkish higher education?

\begin{tabular}{|c|c|}
\hline & $\begin{array}{l}\text { Frequency Out of } 20 \\
\text { participants }\end{array}$ \\
\hline \multicolumn{2}{|l|}{ Positive } \\
\hline It started an important reform process for Turkish universities & 16 \\
\hline $\begin{array}{l}\text { It helped to create a culture in harmony with the international } \\
\text { environment/Integration with the international world }\end{array}$ & 15 \\
\hline It helped a common discourse nation-wide & 13 \\
\hline It created awareness on the inadequacies of the system as a whole & 12 \\
\hline $\begin{array}{l}\text { It helped revising program outcomes, learning outcomes and credits } \\
\text { based on student workload }\end{array}$ & 11 \\
\hline It focused on rationality and reduced arbitrariness & 8 \\
\hline $\begin{array}{l}\text { New terms, such as qualifications framework, student workload, } \\
\text { learning outcomes were introduced to the discussions }\end{array}$ & 8 \\
\hline Stakeholders were noticed and became important & 7 \\
\hline Student centredness and students became noticed & 6 \\
\hline Relations with the employers started & 5 \\
\hline Teaching methods and materials were revised & 5 \\
\hline It focussed on quality assurance and accreditation & 5 \\
\hline \multicolumn{2}{|l|}{ Negative } \\
\hline $\begin{array}{l}\text { Resistance of the academics/past habits clash with the new } \\
\text { requirements of the BP }\end{array}$ & 16 \\
\hline $\begin{array}{l}\text { Formal procedures and proforma implementation are implemented, } \\
\text { rather than the real contents }\end{array}$ & 15 \\
\hline Too much bureaucracy & 13 \\
\hline $\begin{array}{l}\text { Different types of universities were expected to have the same } \\
\text { standards }\end{array}$ & 12 \\
\hline Stakeholders cannot see it as a whole system & 12 \\
\hline Standardization versus diversity & 9 \\
\hline $\begin{array}{l}\text { Implementation is done top-down, which sometimes confuses the } \\
\text { real logic behind each tool }\end{array}$ & 9 \\
\hline No effect on the three-cycle system, we already had & 5 \\
\hline It extended the study period of some students because of the ECTS & 3 \\
\hline It reduced the trainings in technical programs because of the ECTS & 2 \\
\hline
\end{tabular}

particular. They thought they knew the subject well and taught it for many years. In some other cases, particularly in the newly established universities, teaching hours of the staff members are high due to the insufficient numbers of academic staff. They resisted revising the learning outcomes or revising their curriculum, claiming the lack of time. As a result, they tend either to copy the learning outcomes from other programs, or ask a junior fellow to do it without considering the logic. They fulfilled the basic requirements and paperwork asked by the upper bodies without internalizing the implementation. Creating bureaucracy is also a widely shared impact, depending on their experience with defining learning outcomes, program 
outcomes, ECTS credits based on student workload and all paperwork during this process. Academic staff, in particular, are not motivated to revise the credits and contents of their courses for the sake of some new paperwork, especially without a pay raise for this new workload. There are two other comments that require further explanation. One is that the BP is not seen as a unified and interrelated system. The other comment is that the BP brought standardization to programs, and there is no longer any room for diversity. These two comments are interrelated and in fact are the outcomes of the longstanding problems in the system itself. Higher education institutions used to work in their closed circles and they are learning to open up their systems to the outside. Standardization versus diversity is also discussed in other topics of the system. The numbers of higher education institutions increased in a short time and, in order to maintain quality of the services, either recruitment, admissions, program requirements or governance and finance, YÖK imposes certain standards on the higher education institutions. This is one of the urgent problems that need to be solved; and, in each draft of the new law, it is mentioned somehow. Higher education institutions are diverse and their conditions and needs are different, but the system as it stands puts them all in the same category. In addition to this standardization, some top-down requirements of YÖK in relation to the Bologna tools are, therefore, regarded as standardization. For example, the student representatives stated that the study periods were extended because of the ECTS and some training programs were removed in the technical programs.

For question three, the participants were asked "what kind of experience did you have during implementation at your university?" to see the challenges of implementation in each individual institution. This question was not asked to the President of YÖK and the representative of the MoNE, as it is inapplicable to them (Table 3).

It is unsurprising that mobility and transparency are at the top of the list of the positive impacts of the BP in the participants' institutions. Particularly credit mobility is the concrete and short-term outcome of the BP in Turkey. Turkish higher education institutions and students are eager to benefit from the mobility programs. Although Turkey is among the top five countries in terms of Erasmus budget, it is insufficient for all students who wish to participate in the program. As an outcome of transparency, awareness about the university's resources, programs, human capacity, and teaching practices was increased. Another comment by the participants calls attention to monitoring, evaluation, and revision of the programs. The BP provided the groundwork and motivation for the programs and higher education institutions that want to compete with national and international counterparts. Bologna Coordination Committees in each higher education institution in faculties and departments facilitated the coordination and knowledge transfer. Furthermore, students, as the central actor of higher education, started to be involved in curriculum developments, internal quality assurance mechanisms, and calculating workload. Students' interests in the BP is, however, not as high as it should be. Implementation touched their lives only when they wanted to be exchange students. 
Table 3 What kind of experience did you have during the implementation at your university?

\begin{tabular}{l|l}
\hline & $\begin{array}{l}\text { Frequency Out of 18 } \\
\text { participants }\end{array}$ \\
\hline Positive & 14 \\
\hline Mobility is increased & 12 \\
\hline Transparency is increased & 12 \\
\hline Program revisions and evaluation for the courses started & 11 \\
\hline More coordination between different programs within the university & 10 \\
\hline Students became more visible in curriculum developments & 7 \\
\hline $\begin{array}{l}\text { Awareness was increased about the university's resources, } \\
\text { programs, human capacity, teaching practices }\end{array}$ & \\
\hline Negative & 15 \\
\hline Resistance by the senior staff members to the reforms & 14 \\
\hline Mainly formal implementation has not affected the bottom & 12 \\
\hline Bureaucracy increased & 12 \\
\hline $\begin{array}{l}\text { Unwillingness to cooperate within the university/Reaction to } \\
\text { top-down process }\end{array}$ & 6 \\
\hline No clear outcomes for quality and content & 5 \\
\hline Not enough sustainable and consistent steps for monitoring & 3 \\
\hline $\begin{array}{l}\text { University governance used it as a legitimation for their decisions to } \\
\text { the students }\end{array}$ & \\
\hline
\end{tabular}

The negative issues are almost identical with the previous question, such as resistance, proforma and top-down implementation, and increased bureaucracy. Resistance comes mainly from the senior academic staff who do not want to get involved with new paperwork. Lack of academic staff, both in terms of quality and quantity in small cities where higher education institutions were recently established, puts pressure on current academic staff who need to give many courses. They are reluctant about a heavier workload. Even if they prepare the required documents, such as learning outcomes, they tend to be pro forma, not representing the reality. Participants who mentioned these issues point out that negative implication mainly resulted from the false mechanisms developed for the implementation within the institution. Without understanding the logic and the necessity of the tools, both leaders and academic staff see them as requirements asked by their chairs or directors.

The final question was "based on your experiences, which priorities should EHEA have for the coming decade? Should the structural reforms continue or should there be new priorities?" (Table 4).

The final question is the main one to discover the priority areas for the future of the BP. Answers are unsurprising. The participants mention more focus on mobility, quality and cooperation with the rest of the world. Mobility is both inevitable and a demand for a more inclusive, quality assured and qualified higher education. After the massification of higher education in the 2000s in Turkey, higher education institutions started to enjoy increasing numbers of both outgoing 
Table 4 Should the structural reforms continue or should there be some new priorities?

\begin{tabular}{l|l}
\hline & $\begin{array}{l}\text { Frequency Out of 20 } \\
\text { participants }\end{array}$ \\
\hline Mobility should be supported more & 17 \\
\hline Quality assurance should be mentioned with more concrete tools & 16 \\
\hline Practical, simple, easy to implement tools must be introduced & 16 \\
\hline $\begin{array}{l}\text { Cooperation with the rest of the world (more efficient policy forum } \\
\text { mechanisms) should be established }\end{array}$ & 13 \\
\hline $\begin{array}{l}\text { Impact analysis of the implementations in each member } \\
\text { state/control mechanisms for the impacts }\end{array}$ & 13 \\
\hline More concrete terms and targets, rather than artificial ones & 13 \\
\hline Dichotomy between the standards or diversity should be handled & 11 \\
\hline $\begin{array}{l}\text { Best practices and more experience sharing programs should be } \\
\text { planned }\end{array}$ & 10 \\
\hline Joint degrees must be encouraged as a significant tool & 10 \\
\hline Quality of doctoral education should be secured & 9 \\
\hline More and concrete coordination with the business world & 9 \\
\hline More cooperation with the US system, as its less complicated & 9 \\
\hline $\begin{array}{l}\text { New mechanisms for countries according to their implementation } \\
\text { levels }\end{array}$ & 8 \\
\hline More exchange of information about implementation experiences & 7 \\
\hline Clear targets and tools for EHEA-ERA cooperation & 5 \\
\hline More data and info about the graduates & 5 \\
\hline Internationalisation should be defined clearly as a new tool & 5 \\
\hline More cooperation between national student councils & 3 \\
\hline
\end{tabular}

and incoming students. It is considered an indication of prestige to have more international students. There is, however, a drawback in this approach, because for some leaders internationalization is equal to mobility. Therefore, to receive more international students is considered enough and no need is seen to endeavour for qualifications, learning outcomes, quality assurance, etc. It is, however, clear that without providing quality assurance of the qualifications, mobility will be unsustainable. The participants in my interviews, however, know the essence of the BP tools and recommend mobility, quality and cooperation with the world outside Europe as the priorities for the future. In order to increase the implementation level, they recommend easy-to-implement tools, more concrete terms, systematic targets and other monitoring methods in addition to stocktaking reports. Some participants suggested impact analysis to see implementation levels of the BP more realistically, as they regarded the self-evaluation feature of the stocktaking reports a shortcoming. Another suggestion is encouraging and rewarding the best practice examples, such as the DS labels, best mobility practice or best learning outcome definitions. In relation to this, new mechanisms are suggested for countries according to their implementation levels, or bilateral cooperations between the countries that share the similar experiences. More information exchange regarding 
implementation steps is another topic called for by the interviewees. In Turkey, the BFUG structure is not interactive with the stakeholders, and key actors mention the need for an exchange of experiences. Lastly, a suggested priority is a more intense cooperation between the EHEA and the European Research Area (ERA). One of the interviewed vice-rectors in particular stated that accelerating the joint degree programs would be the best and the most concrete solution, both to combine higher education and research activities, and also to promote the true implementation of the structural Bologna reforms.

\section{Concluding Remarks and Recommendations}

This article started with the aim that the Turkish experience of implementing the BP might set an example for the future planning of the EHEA. From the implementation experience and the interviews with key Turkish higher education actors, the following points come to the fore.

The BP had positive impacts on the higher education system and on higher education institutions, even if pro forma or artificial implementation was also seen in some cases. It maintained a common discourse both within the institutions and the countries, as well as internationally. Mobility is the visible outcome and reason for the motivation. The major contribution of the BP to Turkish higher education was to increase the awareness and level of internationalization. Although Turkey has had the three-cycle system since 1981 and did not need to adjust its degree structure, the BP helped in reforming the curricula, defining the learning outcomes, and restructuring the programs with clear outcomes; and designing the national qualifications framework for higher education, which is not self-certified yet.

Negative reflection, however, is mainly due to the pro forma, artificial implementations or structural reform needs of the system. Another reason for the negative impact is the lack of interest in the BP among policymakers, academic staff and students. If the BP is not seen as a unified system, a patchwork approach does not make any sense for concrete outcomes. Another reason is that the internal agenda of each higher education institution does not prioritize proper implementation. Regulations are being forwarded by YÖK top down, and if the higher education institution does not have a strategy for quality or for the qualifications of its graduates, the regulations only become a formal, bureaucratic issue to follow. Policymakers in a national context are not yet fully convinced of the necessity of the BP, although quality assurance, mobility and internationalization have been popular terms on the higher education agenda. The system has longstanding and crucial issues to be solved, such as reforming the governing structure of higher education, including the related law and the position of the YÖK. Therefore, sustainability remains a critical issue since the agendas of decision-makers, higher education institutions, academic staff and students are not focused on the content of the BP. 


\subsection{Recommendations for the Future}

Examining the Turkish experience of the Bologna implementations some recommends come to the fore for the future of the EHEA.

1. New tools and mechanisms should be introduced to increase mobility: It is already a priority for the EHEA as the $20 \%$ by 2020 target was accepted in LeuvenLouvain-la-Neuve and a mobility strategy was recommended in Bucharest. 17 out of 20 of the interviewees in my study mentioned the importance of mobility for the future of higher education. The reason might be the limited budget of Erasmus programs for outgoing students compared to student population in Turkey; and for incoming students, although higher education institutions show great interest and numbers are again low compared to the total student population. Therefore, from a Turkish perspective, mechanisms for bilateral agreements and joint degree programs can be simplified and accelerated. The mobility of young researchers can be focused on to provide longer and sustainable mobility based on mutual research partnerships. The new and nationally financed mobility programs such as Mevlana can be examples for exporting the Bologna tools for a more qualified, transparent and comparable higher education systems.

2. The majority of the key actors interviewed supported more practical, simple, easy-to-implement tools. Some higher education institutions, even if they try to implement the BP tools wholeheartedly, tend to follow the American system, which has easier steps. It is particularly stated that the previous version of the ESG was too complicated; some programs use ABET accreditation and find it more practical. Another item is that ECTS credits do not help with program curriculum flexibility. For example, some participants mentioned that training programs cannot be included because of 60 ECTS limits per year.

3. The higher education institutions, culture and the history of higher education in the 47 EHEA countries are diverse; therefore implementation levels and needs are also diverse. In the future, communication tools between countries and other members, and also public authorities and related institutions within each country should be further developed and diversified. For example, in addition to BFUG meetings, other interactions between national authorities and also institutions should be created. The participation levels of different national authorities in the BP need to be increased. More bilateral dialogues between countries should be encouraged. Other mechanisms for information exchange regarding implementation experiences at an institutional level would be useful, since it would give the opportunity for higher education institutions to establish concrete cooperation and identify problem areas in implementation. In a similar way to the ENIC and NARIC networks, individual institutions could exchange experiences in EHEA networks.

4. Best practices and other rewards like labels encourage institutions, as is the case for DS and ECTS labels. They were highly motivating for Turkish higher education institutions. Institutional experiences and targets created a dynamism 
among the related units within and between the higher education institutions. Similar mechanisms will help higher education institutions adopt more experience sharing and dialogue for the motivation and sustainability of the common tools in the coming decade. Mechanisms such as peer-learning activities, direct contacts and cooperation between countries and institutions on different topics, and more networking between higher education institutions on a national and international scale within and out of EHEA can be planned. Projects for establishing peer-learning activities can be promoted by the official EHEA website where individual institutions can have direct contacts and start joint projects on their preferred topics.

5. As a priority area, joint degree programs between higher education institutions can be focused and promoted in the coming years. They will accelerate EHEA and ERA cooperation and as a concrete sign of the proper implementation. The European Commission's 2020 targets include priorities directly related to higher education, such as increasing employment rates and tertiary education levels. Joint degree programs can be used as a tool, which includes major Bologna mechanisms like easily recognizable and comparable qualifications, mobility of students and staff and quality assurance agreed by both institutions. In addition, joint degree programs maintain internationalization of the curriculum. Therefore, joint degree programs should be encouraged as a significant tool and higher education institutions can be incentivized by certain rewards for their proper implementations.

6. The Bologna Process has stimulated international interest in regional cooperation and tools in the higher education area. The Bologna Policy Forum can be more intensely used in order to extend relations to the rest of the world. Both within the EHEA, as 19 countries are not members of the EU, and beyond the EHEA, inclusion and diversity must be more clearly targeted. Within the EHEA, the current chairing system is a positive step toward this inclusion. At lower levels, participative mechanisms, such as co-chairing of the working groups, or hosting a working group meeting can be extended to each level. Clearer, concrete tools and cooperation methods with the rest of the world should be established. The related working groups can design regional reports or projects for different parts of the world, or a memorandum of understanding can be signed with different countries to share experiences.

To conclude, the Bologna Process is a unique format, based on voluntary engagement and commitment of the countries. At this stage, whether or not it is sustainable to continue with implementation based on the assumption that each country is responsible for its own implementation and for reporting on its results, or if there is a need for more enforcement mechanisms to achieve a comparable, transparent and competitive EHEA, needs to be discussed. Moreover, it has to be emphasized that the EHEA is not limited to the EU. 19 out of the 47 EHEA countries are non-EU, therefore the domination of the EU perspective does not promote the inclusion of all countries. In policy making processes and in decision making this crucial detail should not be ignored. The motivation and the interrelations of the 
Table 5 Summary of Bologna process implementations in Turkey

\begin{tabular}{|c|c|c|c|c|c|c|}
\hline & $\begin{array}{l}\text { Degree } \\
\text { systems }\end{array}$ & Quality assurance & Recognition & $\begin{array}{l}\text { Social } \\
\text { dimension }\end{array}$ & Mobility & $\begin{array}{l}\text { Lifelong } \\
\text { learning }\end{array}$ \\
\hline 2001 & $\begin{array}{l}3 \text { cycle system } \\
\text { already exists } \\
\text { since } 1981\end{array}$ & & & & & \\
\hline 2003 & $\begin{array}{l}3 \text { cycle system } \\
\text { already exists }\end{array}$ & & & & & \\
\hline 2005 & $\begin{array}{l}3 \text { cycle system } \\
\text { already exists }\end{array}$ & $\begin{array}{l}\text { Regulation in line } \\
\text { with ESG and } \\
\text { establishment of } \\
\text { theYÖDEK/ADEKs }\end{array}$ & $\begin{array}{l}\text { Starting the } \\
\text { implementation } \\
\text { of DS and } \\
\text { ECTS with a } \\
\text { regulation by } \\
\text { YÖK }\end{array}$ & $\begin{array}{l}\text { Setting up } \\
\text { the National } \\
\text { Student } \\
\text { Council }\end{array}$ & $\begin{array}{l}\text { Starting to } \\
\text { benefit from } \\
\text { EU Youth and } \\
\text { Education } \\
\text { Programs } \\
\text { (Socrates, } \\
\text { Ersamus, } \\
\text { Leonardo etc.) }\end{array}$ & \\
\hline 2007 & $\begin{array}{l}\text { Starting to } \\
\text { work on the } \\
\text { NQF }\end{array}$ & $\begin{array}{l}\text { Collecting the } \\
\text { annual ADEK } \\
\text { reports from the } \\
\text { HEIs }\end{array}$ & $\begin{array}{l}\text { Lisbon } \\
\text { Recognition } \\
\text { Convention, } \\
\text { signed in 2004, } \\
\text { came into force }\end{array}$ & & & \\
\hline \multirow[t]{2}{*}{2009} & $\begin{array}{l}\text { Work on the } \\
\text { NQF is } \\
\text { intensified, } \\
\text { national } \\
\text { commission } \\
\text { and working } \\
\text { group } \\
\text { established }\end{array}$ & $\begin{array}{l}\text { Bologna } \\
\text { Coordination } \\
\text { Committees in each } \\
\text { HEI established and } \\
\text { principles and } \\
\text { guidelines prepared } \\
\text { nationally }\end{array}$ & $\begin{array}{l}\text { Encouraging } \\
\text { HEIs to apply } \\
\text { for ECTS and } \\
\text { DS labels }\end{array}$ & $\begin{array}{l}\text { Enrolment } \\
\text { rates } \\
\text { increased } \\
\text { with new } \\
\text { universities } \\
\text { and places } \\
\text { in each } \\
\text { program }\end{array}$ & $\begin{array}{l}\text { To increase } \\
\text { long term } \\
\text { mobility } \\
\text { encouraging } \\
\text { HEIs for } \\
\text { bilateral } \\
\text { agreements. } \\
\text { Nationwide } \\
\text { mobility } \\
\text { program Farabi } \\
\text { started }\end{array}$ & $\begin{array}{l}\text { LLL } \\
\text { Strategy } \\
\text { Paper was } \\
\text { prepared } \\
2009-2013 \\
\text { by the } \\
\text { Ministry of } \\
\text { Education }\end{array}$ \\
\hline & $\begin{array}{l}\text { Degree } \\
\text { Systems }\end{array}$ & Quality Assurance & Recognition & $\begin{array}{l}\text { Social } \\
\text { Dimension }\end{array}$ & Mobility & $\begin{array}{l}\text { Lifelong } \\
\text { Learning }\end{array}$ \\
\hline 2010 & $\begin{array}{l}\text { NQF prepared, } \\
\text { Field } \\
\text { Qualifications } \\
\text { Prepared, Pilot } \\
\text { HEIs chosen to } \\
\text { implement } \\
\text { NQF }\end{array}$ & $\begin{array}{l}\text { Quality Assurance } \\
\text { Agencies } \\
\text { (MUDEK, FEDEK, } \\
\text { and for a few other } \\
\text { programs were } \\
\text { approved by } \\
\text { YÖDEK }\end{array}$ & $\begin{array}{l}\text { Encouraging } \\
\text { HEIs to apply } \\
\text { for ECTS and } \\
\text { DS labels }\end{array}$ & $\begin{array}{l}\text { Asking } \\
\text { HEIs to } \\
\text { design more } \\
\text { flexible } \\
\text { programs } \\
\text { allowing } \\
25 \% \\
\text { elective } \\
\text { courses }\end{array}$ & & \\
\hline
\end{tabular}


Table 5 (continued)

\begin{tabular}{|c|c|c|c|c|c|c|}
\hline & $\begin{array}{l}\text { Degree } \\
\text { systems }\end{array}$ & Quality assurance & Recognition & $\begin{array}{l}\text { Social } \\
\text { dimension }\end{array}$ & Mobility & $\begin{array}{l}\text { Lifelong } \\
\text { learning }\end{array}$ \\
\hline 2011 & $\begin{array}{l}\text { Amendment in } \\
\text { HE Act to } \\
\text { include } \\
\text { Bologna tools } \\
\text { such as credits } \\
\text { compatible } \\
\text { with ECTS, } \\
\text { and based on } \\
\text { Learning } \\
\text { Outcomes }\end{array}$ & & & & $\begin{array}{l}\text { A new } \\
\text { exchange } \\
\text { program } \\
\text { Mevlana for } \\
\text { students and } \\
\text { academic staff } \\
\text { covering the } \\
\text { countries out of } \\
\text { the EU region } \\
\text { was started }\end{array}$ & \\
\hline 2013 & & & $\begin{array}{l}\text { The number of } \\
\text { HEIs receiving } \\
\text { DS and ECTS } \\
\text { labels increased }\end{array}$ & & & \\
\hline 2014 & & $\begin{array}{l}\text { YÖKAK } \\
\text { established and } \\
\text { started to prepare a } \\
\text { new regulation for } \\
\text { QA }\end{array}$ & & & & \\
\hline
\end{tabular}

Table 6 Profile of the participants

\begin{tabular}{l|l}
\hline President, YÖK & Public \\
\hline MoNE & Public \\
\hline Rector & Public \\
\hline Rector & Public \\
\hline Rector & Public \\
\hline Rector & Public \\
\hline Rector & Public \\
\hline Rector & Public \\
\hline Rector & Public \\
\hline Rector & Foundation \\
\hline Rector & Foundation \\
\hline Ex-rector & Public \\
\hline Vice-rector & Public \\
\hline Vice-rector & Public \\
\hline Vice-rector & Foundation \\
\hline Bologna expert & Public \\
\hline Bologna expert & Public \\
\hline Student & Public \\
\hline Student & Public \\
\hline Student & Public \\
\hline &
\end{tabular}


non-EU countries such as Azerbaijan, Georgia, Kazhakstan, Russia, and Ukraine can be provided by inclusive approaches, programs and procedures. The prospects, structure, and targets of the EHEA need to be pursued through a more inclusive and participative approach after the experiences of the past fifteen years and given its 47 members. Turkey remains as a unique member of the EHEA for historical, cultural and structural reasons. Its ties with different regions such as Central Asia, the Balkans, the Mediterranean, and the Middle East give potential for further cooperation to improve the attractiveness of the EHEA (Tables 5 and 6).

Open Access This chapter is distributed under the terms of the Creative Commons Attribution Noncommercial License, which permits any noncommercial use, distribution, and reproduction in any medium, provided the original author(s) and source are credited.

\section{References}

Altbach, P. G., Gumport, P. J., \& Berdahl, R. O. (Eds.). (2011). American higher education in the twenty first century: Social, political and economic challenges. Baltimore: John Hopkins University Press.

Altbach, P. G., \& Peterson, P. M. (Eds.). (1999). Higher education in the 21st century: Global challenge and national response. IIE.

Altbach, P. G., Reizberg, L., \& Rumbley, L. E. (2009). Trends in higher education: Tracking an academic revolution. A Report Prepared for the UNESCO 2009 World Conference on Higher Education. UNESCO.

Arnove, R. F., Torres, C. A., \& Franz, S. (2012). Comparative education: The dialectic of the global and the local. Plymouth: Rowman and Littlefield Publishers.

Bloom, D. E. (2005). "Raising the pressure: Globalization and the need for higher education reform. In G. A. Jones, P. L. McCarney \& M. L. Skolnik (Eds.), Creating knowledge, strengthening nations: The changing role of higher education (pp. 21-42). University of Toronto Press

Bologna Process. (2009). Communiqué of the conference of European ministers responsible for higher education, Leuven and Louvain-la-Neuve. http://www.ehea.info/Uploads/Declarations/ Leuven_Louvain-la-Neuve_Communiqu\%C3\%A9_April_2009.pdf

Bologna Process. (2012). Making the most of our potential: Consolidating the European higher education area. http://www.ehea.info/Uploads/\%281\%29/Bucharest\%20Communique\% 202012\%281\%29.pdf

Çetinsaya, G., (2014). Büyüme, Kalite, Uluslararasılaşma: Türkiye Yükseköğretimi için bir Yol Haritası (Enlargement, quality, internationalisation: A road map for turkey's higher education) Eskișehir: Anadolu Üniversitesi. https://yolharitasi.yok.gov.tr/docs/YolHaritasi.pdf

Cortese, A. (2003). The critical role of higher education in creating a sustainable future. http:// www.aashe.org/resources/pdf/Cortese_PHE.pdf

EHEA, European Higher Education Area. (2012). Bologna process implementation report. Retrieved from http://www.ehea.info/Uploads/\%281\%29/Bologna\%20Process\%20Implementation\%20Report.pdf

Elmas, M. (2012). Bologna Süreci: Uygulama veya Uygulayamama (Bologna process: Apply or not apply). Yüksekögretim ve Bilim Dergisi, 2(3), 137-141.

Enders, J. (2004). Higher education, internationalisation and the nation state: Recent developments and challenges to governance theory. Higher Education, 47, 361-382. 
Erdoğan, A., Toprak, M. (2012). Governance of higher education in Turkey. In Leadership and governance in higher education for decision-makers and administrators, C. 3. Berlin: Raabe Verlag.

Erdoğan, A. (2013). Türk Yükseköğretiminin Yeniden Yapılanma Çalışmaları: Küresel Eğilimler ve Uluslararasılaşma Çerçevesinde Değerlendirmeler. Reforming Turkish Higher Education: Evaluations under Global Trends and Internationalization' Stratejik Düșünce Enstitüsü-SDE, Ankara.

Erdoğan, A. (2014). Türkiye’de Yükseköğretimin Gündemi için Politika Önerisi (Policy proposal for higher education agenda in Turkey). Yüksekögretim ve Bilim Dergisi, 4(1), 1-17.

Eurydice, (2009). Key data on education in Europe 2009. Brussels: European Commission, EACEA.

Gaston, P. L. (2010). The challenge of Bologna: What United States higher education has to learn from Europe, and why it matters that we learn it. Virginia: Stylus Publishing LLC.

Gibbons, M. (1998). Higher education relevance in the 21st century. Washington DC: World Bank.

HE Act, Turkish Higher Education. (2011). Turkish higher education 2547 (Ed.). Retrieved from http://www.mevzuat.basbakanlik.gov.tr/Metin.Aspx?MevzuatKod=1.5.2547\&MevzuatIliski= 0\&sourceXmlSearch=http://www.yok.gov.tr/documents/

OECD, (2009). Higher education to 2030: globalization (Vol. 2). Paris.

Scott, P. (2005). The opportunities and threats of globalization. In G. A. Jones, P. L. McCarney \& M. L. Skolnik (Eds.), Creating knowledge, strengthening nations: The changing role of higher education (pp. 42-56). Toronto, ON; Buffalo: University of Toronto Press

Scott, J. C. (2006). The mission of the university: Medieval to postmodern transformations. Journal of Higher Education, 77(1), 10-13.

Stromquist, N. P., \& Monkman, K. (Eds.). (2014). Globalization and education: Integration and contestation across cultures. Plymouth: R\&L Education.

Sursock, A., \& Smidt, H. (2010). Trends 2010: A decade of change in European higher education. Brussels: EUA.

Tenth Development Plan 2014-2018. (2013). Retrieved from http://www.kalkinma.gov.tr/Lists/ Kalknma\%20Planlar/Attachments/12/Onuncu\%20Kalk\%C4\%B1nma\%20Plan\%C4\%B1.pdf

Tuzcu, G. (2006). Eğitimde Vizyon 2023 ve AB'ye Giriş Süreci (2023 Vision in Education and Accession to EU). Retrieved from http://portal.ted.org.tr/genel/yayinlar/ EgitimdeVizyon2023veAvrupaBirligineGirisSureci.PDF

YÖK. (2007). Türkiye'nin Yüksekögretim Stratejisi (Strategy of Turkish Higher Education). Ankara: Yükseköğretim Kurulu. 